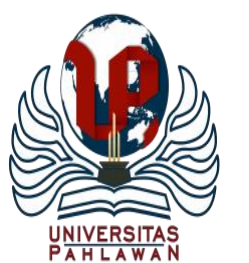

Jurnal Abdidas Volume 2 Nomor 4 Tahun 2021 Halaman 988-994

JURNAL ABDIDAS

http://abdidas.org/index.php/abdidas

\title{
Agrowisata bagi Masyarakat dalam Meningkatkan Jiwa Kewirausahaan di Tenayan Raya Pekanbaru Riau
}

\author{
Nany Librianty ${ }^{1 凶}$, Ramdhan Witarsa $^{2}$, Dini Xena Dista $^{3}$ \\ Kewirausahaan, Universitas Pahlawan Tuanku Tambusai, Indonesia ${ }^{1}$ \\ Pendidikan Guru Sekolah Dasar, Universitas Pahlawan Tuanku Tambusai, Indonesia ${ }^{2,3}$ \\ E-mail: nanilibrianti@ rocketmail.com ${ }^{1}$ drdadan19@gmail.com ${ }^{2}$ dini.bkn123@gmail.com ${ }^{3}$
}

\begin{abstract}
Abstrak
Tenayan Raya merupakan salah satu kawasan di Pekanbaru Riau yang merupakan tempat agrowisata. Tujuan dari kegiatan ini adalah memberikan pengalaman dan pelatihan kewirausahaan kepada masyarakat sekitar dan mahasiswa agar memiliki pengelolaan dan pendampingan kewirausahaan terhadap suatu kawasan tertentu. Kegiatan ini dilakukan sepanjang bulan September hingga Desember 2019. Metode yang digunakan pada kegiatan ini adalah diskusi dan partisipasi aktif dari kelompok masyarakat dan mahasiswa. Hasil yang diperoleh menunjukkan bahwa masyarakat dan mahasiswa telah mengetahui cara pengelolaan kewirausahaan yang baik setelah mengunjungi Agrowisata Tenayan Raya secara praktik, diperolehnya kesadaran mahasiswa akan pentingnya berwirausaha, serta muncul kesadaran mahasiswa akan pentingnya suatu peluang berwirausaha. Dampak dan impact dari kegiatan ini adalah semakin bertambahnya keinginan mahasiswa dalam berwisausaha bersamaan dengan kegiatan kuliah yang mereka ikuti.
\end{abstract}

Kata kunci: agrowisata, Tenayan Raya, kewirausahaan

\section{Abstract}

Tenayan Raya is one of the areas in Pekanbaru, Riau, which is an agro-tourism site. The purpose of this activity is to provide entrepreneurial experience and training to the surrounding community and students to have entrepreneurial management and assistance to a particular area. This activity was carried out from September to December 2019. The method used in this activity was discussion and active participation from community groups and students. The results obtained indicate that the community and students already know how to manage entrepreneurship well after visiting the Tenayan Raya agrotourism in practice, gained student awareness of the importance of entrepreneurship, as well as emerging student awareness of the importance of an entrepreneurial opportunity. The impact and impact of this activity is the increasing desire of students in entrepreneurship along with the lecture activities they are taking.

Keywords: agro-tourism, Tenayan Raya, entrepreneurship

Copyright (c) 2021 Nany Librianty, Ramdhan Witarsa, Dini Xena Dista

$\triangle$ Corresponding author

Address : Universitas Pahlawan Tuanku Tambusai $\quad$ ISSN 2721- 9224 (Media Cetak)

Email : nanilibrianti@rocketmail.com

DOI $\quad$ : https://doi.org/10.31004/abdidas.v2i4.417

ISSN 2721- 9216 (Media Online) 


\section{PENDAHULUAN}

Agrowisata Tenayan Raya merupakan salah satu objek wisata dan kewirausahaan yang ada di Pekanbaru Riau. Obyek wisata ini terletak di Jalan Pesantren- Jalan Kadiran, Kecamatan Tenayan Raya, sekitar $10 \mathrm{~km}$ dari Kota Pekanbaru. Jika menggunakan kendaraan roda empat dari Pekanbaru, cukup 10 menit saja sudah tiba di lokasi ini. Agrowisata milik Adi Prastowo ini dibangun di atas lahan sekitar 6 hektar. Sesuai dengan namanya, objek wisata ini mengkhususkan di bidang agro. Jika kita berkunjung ke tempat ini, suasana pedesaan segera terasa. Selain udara yang segar, pemandangan panorama pertanian yang hijau juga turut menyejukkan suasana (Gunawan, 2016; Kamino, 2015).

Di taman agrowisata ini pengunjung tidak hanya sekadar belajar bercocok tanam, namun juga belajar cara pemeliharaannya dari pembimbing, juga belajar tentang kewirausahaan. Memang, oleh pemiliknya, taman agrowisata ini didirikan dengan konsep agro-edukasi. Di dalam area Taman Agrowisata Tenayan Raya dapat dijumpai berbagai jenis tanaman dan sarana belajar sekaligus bermain. Terdapat banyak tanaman buah dan sayuran seperti ketimun, jambu madu, melon, lengkeng, jagung, gambas, bawang, kangkung, dan cabai. Pengunjung dapat memetik langsung buah dari pohonnya dan ikut panen sayuran serta belajar bagaimana memasarkannya (Muljadi \& Warman, 2014).

Taman Agrowisata Tenayan Raya juga menyediakan area peternakan seperti kolam ikan, kambing, dan unggas. Pengunjung, khsususnya anak-anak, dapat belajar memancing dan memberi makan ikan, atau ikut permainan menangkap ikan lele di kolam. Sementara untuk dewasa, bisa belajar berwirausaha peternakan, dari mulai awal hingga akhir. Di area peternakan kambing, anakanak dapat merasakan memberi makan kambing. Tidak perlu menunggu hari raya Idul Adha untuk bertemu kambing. Selain itu Taman Agrowisata Tenayan Raya juga dilengkapi dengan beberapa fasilitas, antara lain: restauran, flying fox, area panahan, ayunan, saung, kebun jagung, kebun jambu, kebun mangga, kebun lengkeng, sawah, kolam, dan arena outbound (Utama, 2015).

Agrowisata Tenayan Raya cukup terjangkau oleh pengunjung. Pengunjung cukup membayar tiket masuk seharga Rp.5.000,- telah dapat menikmati taman agrowisata. Jika ingin mencoba paket edukasi, setiap anak cukup membayar Rp.50.000. Orang tua dan guru pendamping tidak perlu membeli tiket. Inilah kewirausahaan langsung yang dapat dipelajari oleh mahasiswa dan umum yang ingin berwirausaha (Windia, et all, 2007).

Dengan membeli tiket paket edukasi pengunjung anak-anak dapat mencoba memetik jagung, menanam padi di sawah, memberi makan kambing, kelinci, dan bebek, menanam kangkung, ikut permainan tangkap ikan lele, serta permainan tali gantung, menyeberangi jembatan, dan foto bersama. Jagung yang dipetik dan kangkung yang ditanam di polibag boleh dibawa pulang.

Berdasarkan gambaran yang telah diungkapkan tersebut, nampak jelas bahwa setiap bagian yang ada di Agrowisata Tenayan Raya bisa dijadikan contoh langsung bagi mahasiswa yang ingin berusaha pada bidang jenis yang hampir 
990 Agrowisata bagi Masyarakat dalam Meningkatkan Jiwa Kewirausahaan di Tenayan Raya Pekanbaru Riau -Nany Librianty, Ramdhan Witarsa, Dini Xena Dista

DOI: https://doi.org/10.31004/abdidas.v2i4.417

sama. Nampak di semua bagian di Tenayan Raya bisa dimungkinkan menghasilkan uang dan proses kewirausahaan bisa berjalan lancar.

\section{METODE}

\section{Tempat dan Waktu}

Kegiatan kewirausahaan ini dilakukan di Tenayan Raya Pekanbaru Riau yang beralamatkan di Jalan Kadiran, Kulim, Kec. Tenayan Raya, Kota Pekanbaru, Riau 28289. Kegiatan ini berlangsung selama Desember 2019.

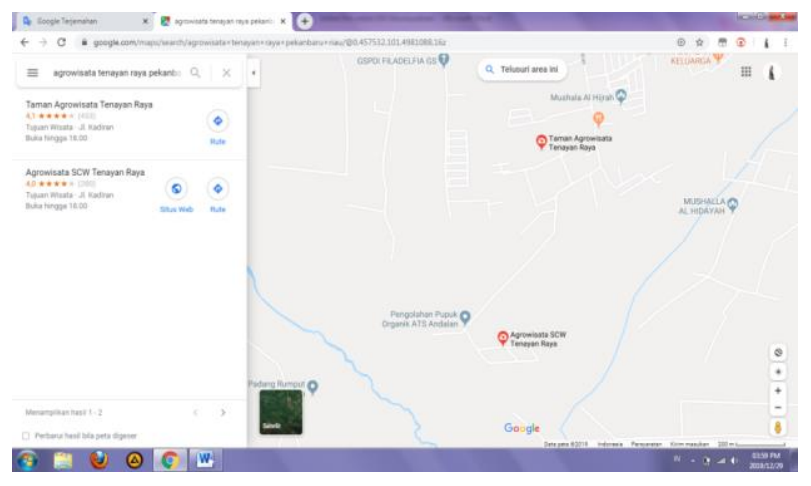

Gambar 1 Peta Lokasi Pelaksanaan Kegiatan Kewirausahaan

\section{Tahapan dan Metode Pelaksanaan} Kegiatan

Kegiatan pelatihan dan pendampingan kewirausahaan di Tenayan Raya ini terdiri dari beberapa tahapan kegiatan sebagai berikut: sosialisasi dan perizinan; persiapan kegiatan dan pendampingan kewirausahaan; kegiatan kewirausahaan; praktik dan pendampingan kewirausahaan; dan evaluasi hasil kegiatan. Adapun jadwal kegiatan disajikan pada Tabel 1.

a. Sosialisasi dan Perizinan
Sosialisasi dan perizinan merupakan tahap awal kegiatan. Kegiatan ini bertujuan untuk menginformasikan kepada pihak Pengelola Agrowisata Tenayan Raya dan mahasiswa mengenai rencana kegiatan. Kegiatan ini dilakukan dengan metode diskusi langsung dengan pihak Pengelola Tenayan Raya dan mahasiswa yang dihadiri oleh Dosen Kewirausahaan.

b. Persiapan Kegiatan dan Pendampingan Kewirausahaan

Persiapan kegiatan dan pendampingan kewirausahaan berupa alat dan bahan yang akan digunakan pada kegiatan dan pendampingan. Alat-alat dan bahanbahan tersebut meliputi: alat tulis, baliho kegiatan, materi kegiatan, serta alat-alat dan bahan-bahan lainya yang digunakan untuk praktik kewirausahaan.

c. Kegiatan Kewirausahaan

Kegiatan kewirausahaan melalui penyuluhan dan diskusi aktif dilakukan melalui penyampaian materi dan diskusi antara pengelola Tenayan Raya dan mahasiswa. Materi yang disampaikan dalam kegiatan ini mencakup: konsep wisata edukasi, hal-hal yang berkaitan dengan dunia pertanian dan peternakan. Pada kegiatan ini juga dilakukan sesi tanya jawab dengan mahasiswa.

d. Praktik dan Pendampingan Kewirausahaan

Kegiatan pelatihan dan pendampingan kewirausahaan ini dimulai dari pemilihan 
991 Agrowisata bagi Masyarakat dalam Meningkatkan Jiwa Kewirausahaan di Tenayan Raya Pekanbaru Riau -Nany Librianty, Ramdhan Witarsa, Dini Xena Dista

DOI: https://doi.org/10.31004/abdidas.v2i4.417

lokasi-lokasi yang menjadi lokasi favorit

bagi pengunjung. Pelatihan dan

pendampingan kewirausahaan ini

dilakukan dengan metode partisipasi

aktif. Lokasi-lokasi yang dipilih

berdasarkan pengamatan dan kesadaran

mahasiswa akan pentingnya wisata

edukasi di Pekanbaru Riau. Berikut

lokasi-lokasi yang dipilih:
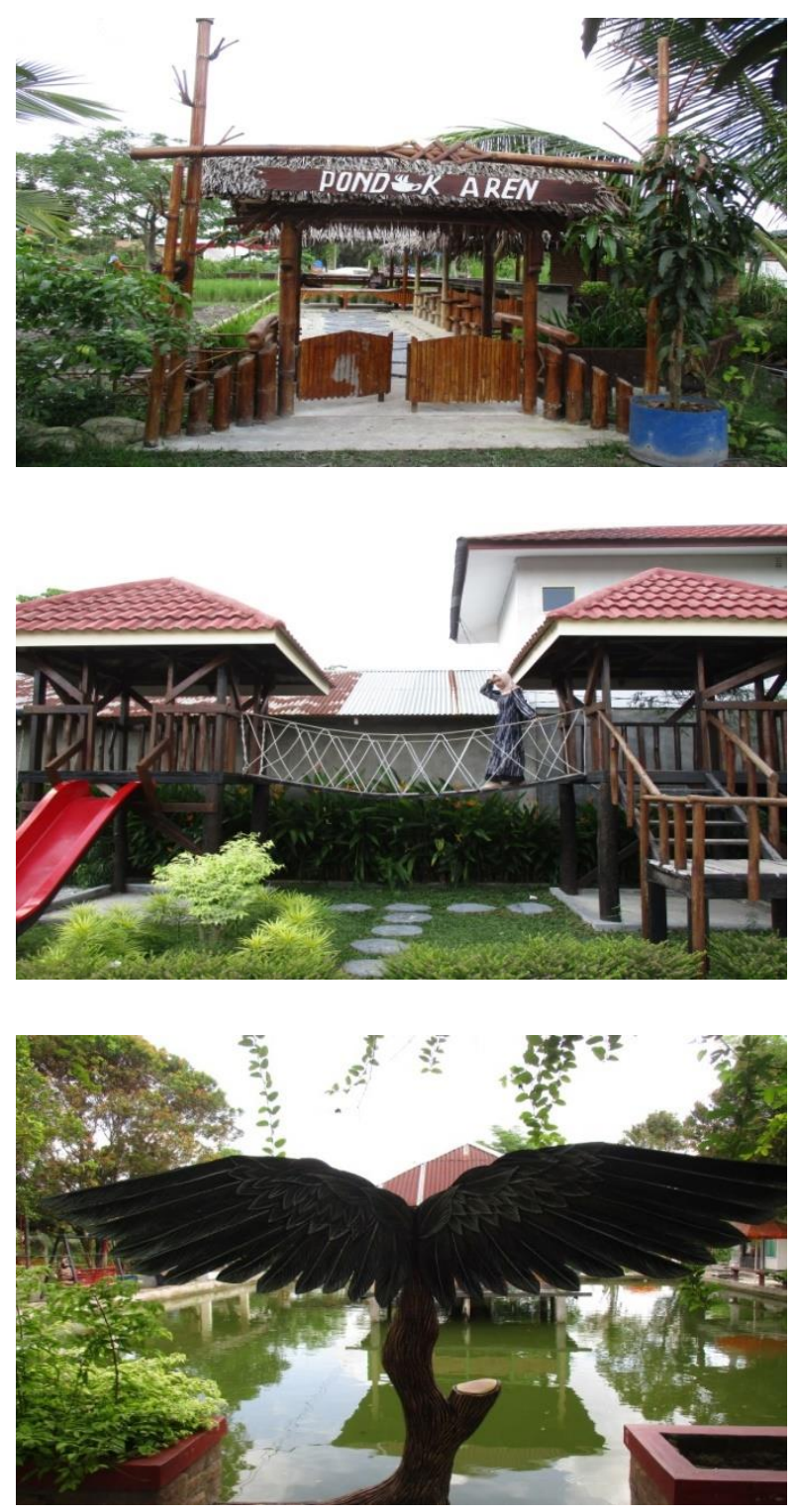

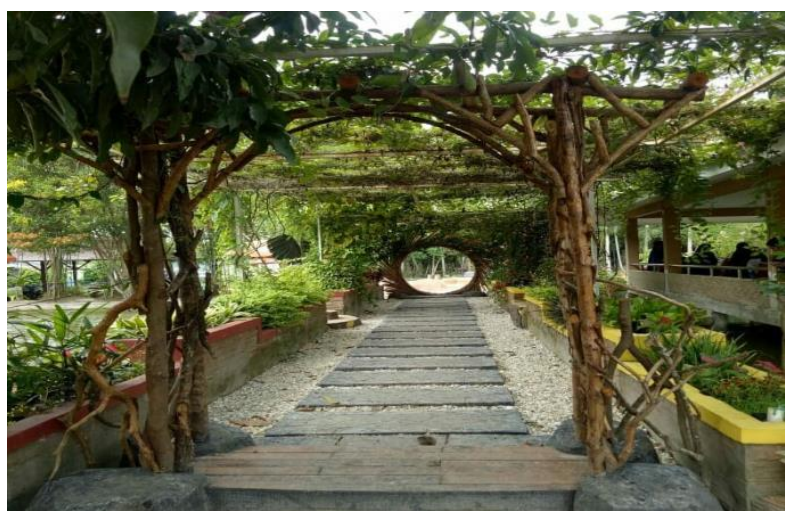

Gambar 2. Tempat Foto-foto bagi Pengunjung
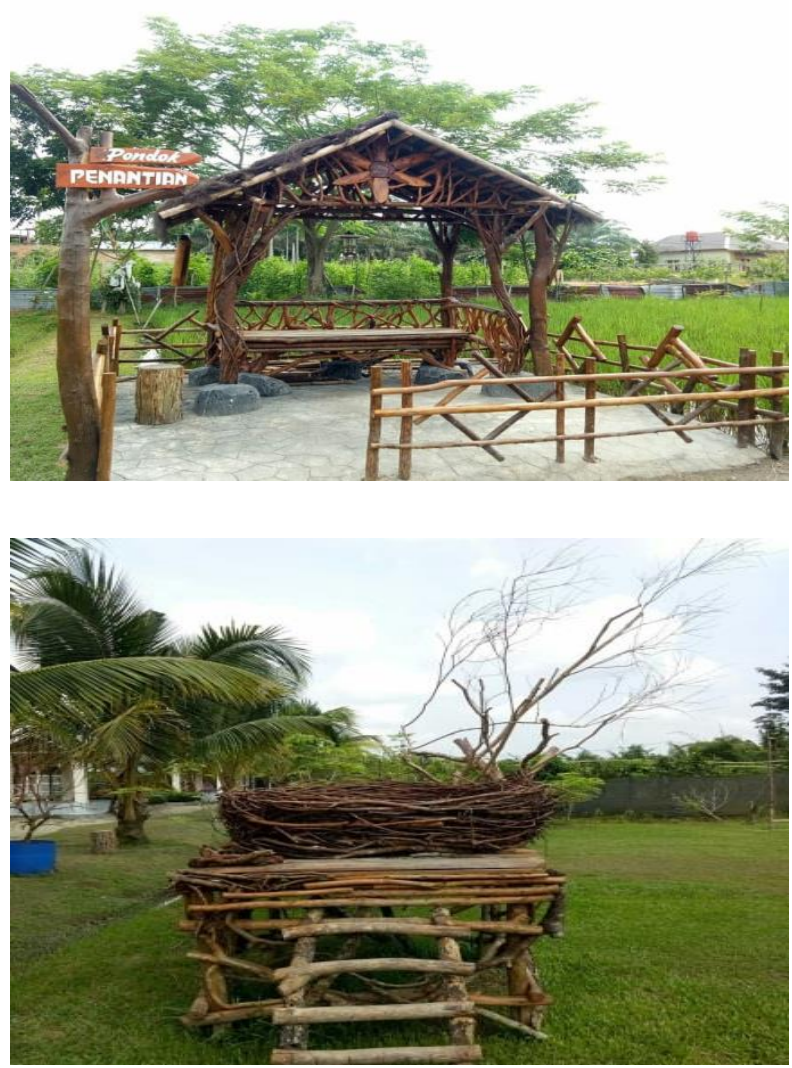

Gambar 3. Pesawahan dan Ladang Tenayan Raya

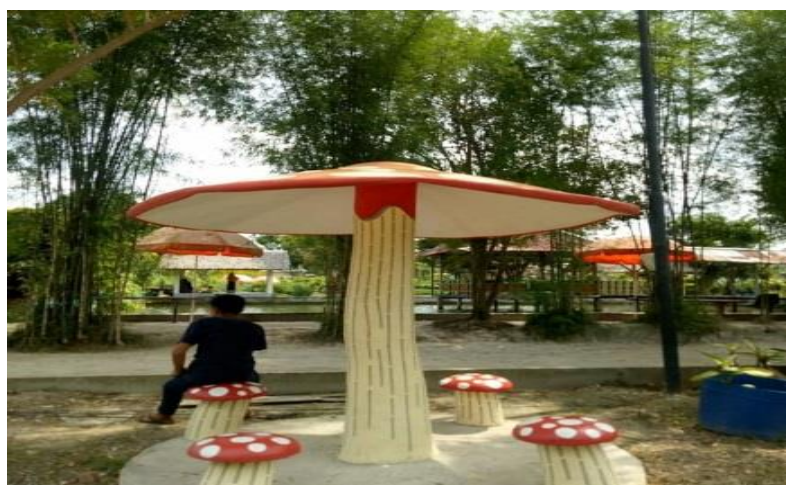




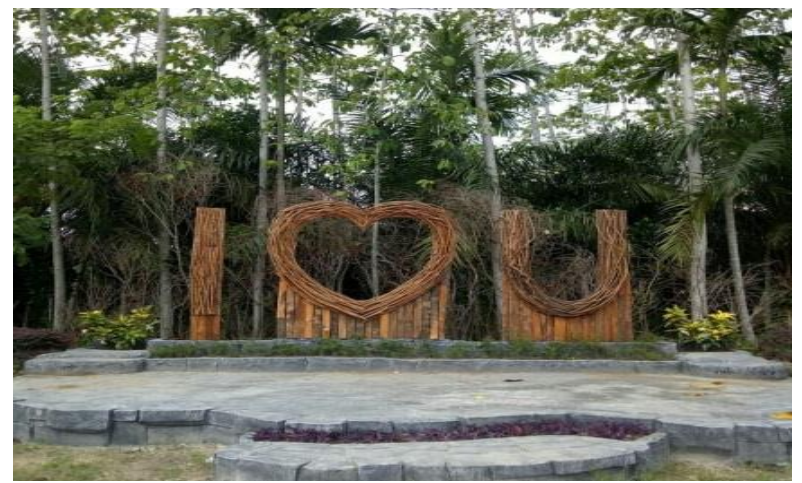

Gambar 4. Gazebo bagi Pengunjung

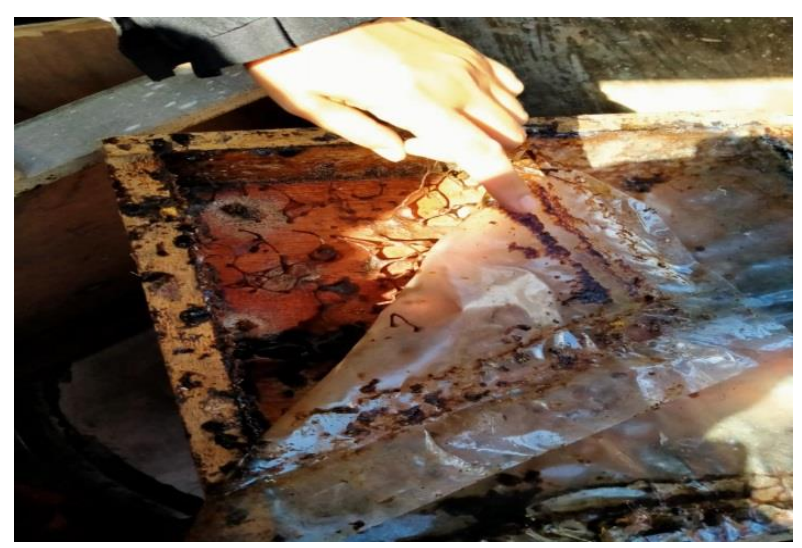

Gambar 5. Peternakan Lebah Tenayan Raya

\section{HASIL DAN PEMBAHASAN}

\section{Hasil Kegiatan Sosialisasi dan Perijinan dengan Pihak Pengelola Tenayan Raya}

Kegiatan penyuluhan dan pemberian materi dari Pengelola Tenayan Raya diawali dengan kegiatan sosialisasi dan perijinan kepada pihak Pengelola Tenayan Raya. Kegiatan ini dilakukan dengan menginformasikan kepada pihak Pengelola Tenayan Raya mengenai tujuan dan rencana kegiatan yang akan dilakukan mahasiswa. Hasil dari kegiatan diskusi tersebut menunjukkan bahwa pihak Pengelola Tenayan Raya sangat antusias dan mengapresiasi kegiatan dan pemberian materi mengenai kewirausahaan. Hal ini terlihat dari hasil wawancara yang dilakukan dengan pihak Pengelola Tenayan Raya yang menyatakan bahwa Tenayan Raya sangat mendukung adanya kegiatan ini guna manambah pengetahuan bagi mahasiswa mengenai kewirausahaan (Mayasari \& Ramdhan, 2013).

Menurut Pengelola Tenayan Raya, selama ini mahasiswa hanya hadir dan fotofoto saja di tempat mereka. Sesekali tanya jawab mengenai hal-hal umum mengenai Tenayan Raya, berbeda dengan kegiatan kali ini yang mengkhususkan sesi tanya jawab seputar kewirausahaan secara detail. Oleh karena itu, kegiatan ini sangat membantu dan mendukung upaya pemerintah dalam mencetak wirausaha-wirausaha muda dan baru (Suyastiri, 2012; Gumelar, 2010).

Setelah melaksanakan kegiatan sosialisasi dan perizinan dengan pihak Pengelola Tenayan Raya, selanjutnya dilakukan kegiatan sosialisasi dengan mahasiswa dan masyarakat yang akan terlibat. Ruang lingkup diskusi awal ini meliputi rencana persiapan kegiatan, pemilihan lokasi pemberian materi kewirausahaan. Luaran dari sosialisasi awal ini adalah adanya kesepakatan dengan mahasiswa mengenai waktu dan tempat pelaksanaan serta kesepahaman akan fungsi dan peran masing-masing. 
993 Agrowisata bagi Masyarakat dalam Meningkatkan Jiwa Kewirausahaan di Tenayan Raya Pekanbaru Riau -Nany Librianty, Ramdhan Witarsa, Dini Xena Dista

DOI: https://doi.org/10.31004/abdidas.v2i4.417

\section{Kegiatan Penyuluhan dan Pemberian} Materi dari Pengelola Tenayan Raya

Kegiatan penyuluhan dilaksanakan setelah kegiatan sosialisasi awal dilaksanakan. Kegiatan ini bertujuan untuk memberikan pengetahuan dan pemahaman secara praktis mengenai jiwa kewirausahaan dan semangat berwirausaha. Kegiatan ini dilakukan dengan metode pemaparan materi yang dilanjutkan dengan sesi tanya jawab. Beberapa pertanyaan yang muncul saat berlangsungnya sesi tanya jawab diantaranya: bagaimana memulai berwirausaha, berapa banyak modal yang dibutuhkan, kalau gagal bagaimana, dan sebagainya.

Kegiatan ini diikuti oleh 41 mahasiswa dari Universitas Pahlawan dan tiga orang dosen yang berkaitan dengan mata kuliah kewirausahaan. Dokumentasi kegiatan disajikan pada Gambar 14 dan seterusnya. Hasil evaluasi awal menunjukkan antusiasme peserta yang tinggi dengan dibuktikan tidak ada satupun mahasiswa yang meninggalkan sesi ini sampai dengan akhir.

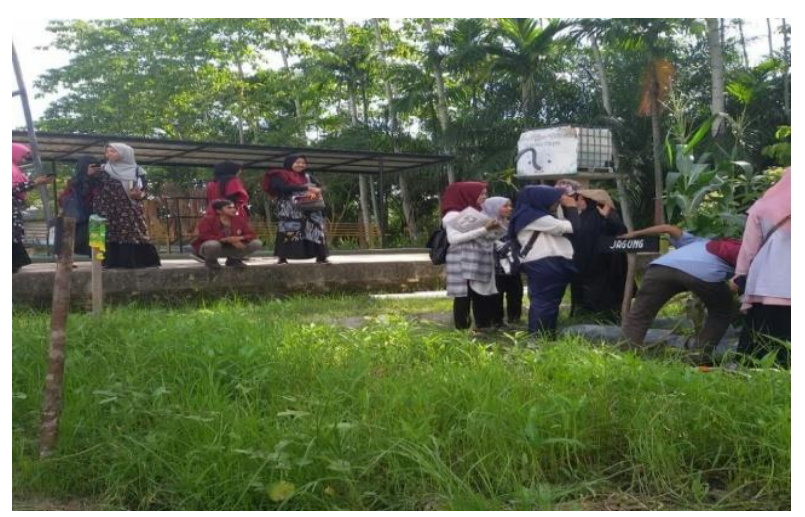

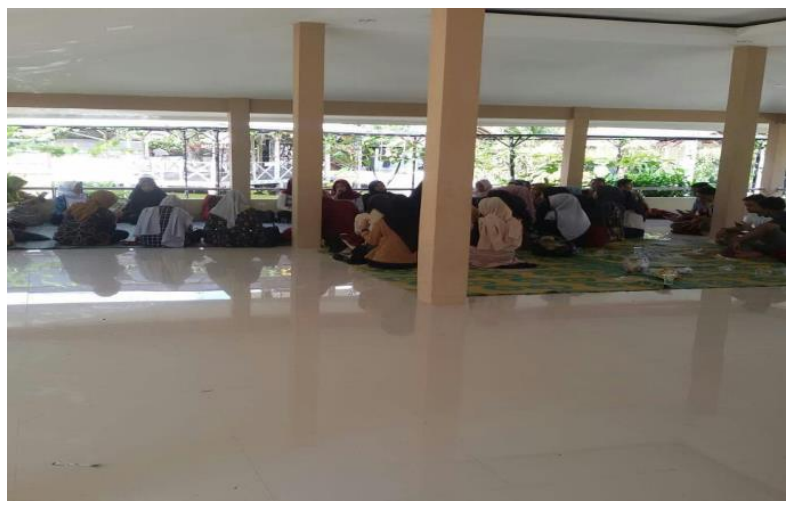

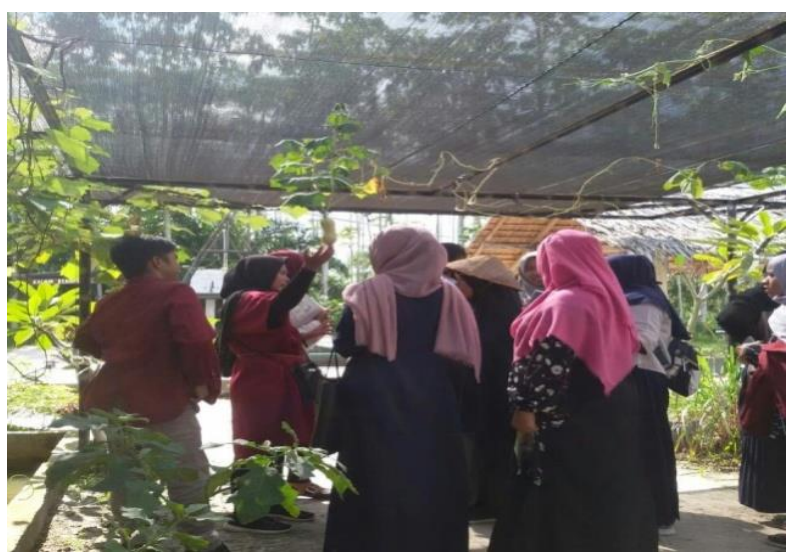

Gambar 6. Sesi Diskusi Mahasiswa dan Pengelola Tenayan Raya

\section{Pelaksanaan Pelatihan Kewirausahaan}

Pelatihan kewirausahaan dimulai dengan pemilihan lokasi kewirausahaan. Kegiatan ini dilakukan secara partisipatif aktif. Pertimbangan yang diambil untuk pemilihan lokasi adalah aspek-aspek ekologi, resiko, dan sosial ekonomi. Berikut foto-foto kegiatan saat pelaksanaan pelatihan kewirausahaan. 


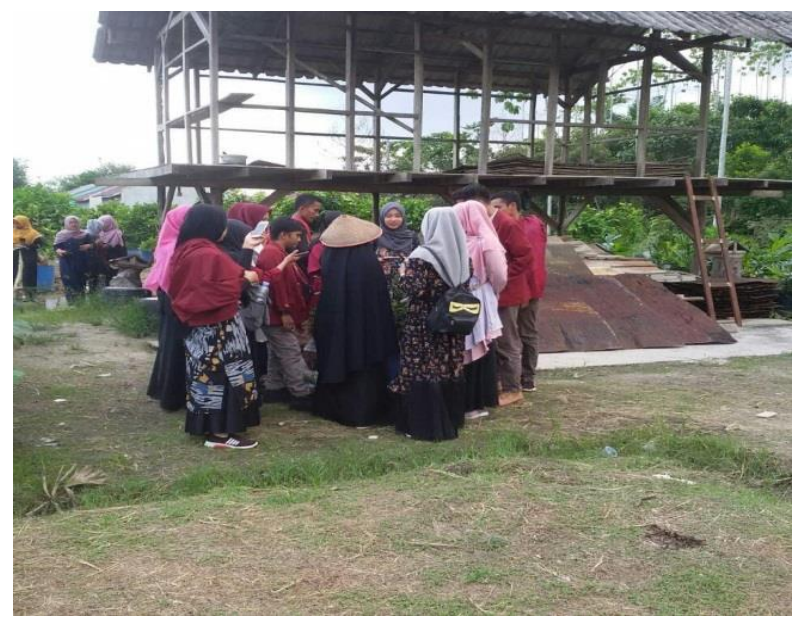

Gambar 7. Sesi Diskusi Kewirausahaan

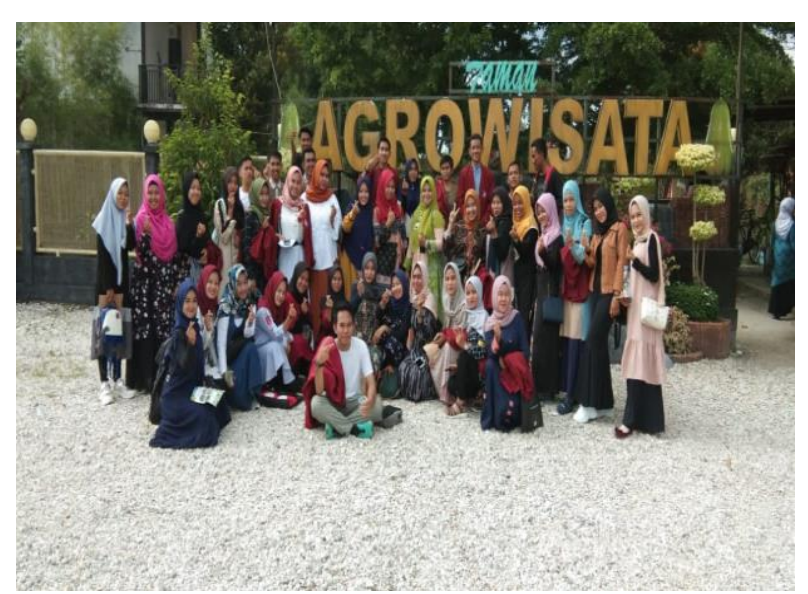

Gamabar 8. Sesi Akhir Kegiatan Kewirausahaan

\section{SIMPULAN}

Kesimpulan hasil kegiatan dan pelatihan yang telah diikuti, maka dapat disimpulkan bahwa Agrowisata Tenayan Raya Pekanbaru Riau serta kelompok masyarakat sekitar sangat mendukung kegiatan pelatihan dan kegiatan kewirausahaan bagi masyarakat dan mahasiswa guna meningkatkan kesadaran dan jiwa kewirausahaan secara langsung, bukan hanya sekedar teori. Jumlah animo mahasiswa untuk berwirausaha pun semakin meningkat.

\section{DAFTAR PUSTAKA}

Gumelar, S.S. (2010). Konsep Pengembangan Kawasan Agrowisata. Handout Mata Kuliah Consept Resort and Leisure, Strategi Pengembangan dan Pengelolaan Resort and Leisure.

Gunawan, I.M. (2016). Pengembangan Agrowisata untuk Kemandirian Ekonomi dan Pelestarian Budaya di Desa Kerta Payangan Gianyar. Jurnal Jumpa (ISSN 2406-9116), 3 (1), 156-174

Kamino, S.S. (2015). Kebijakan Pemerintah Membangun Sektor Pertanian dalam Perspektif Pariwisata dan Membangun Pariwisata dalam Perspektif Pertanian. Makalah Seminar Nasional.9 Oktober 2015.

Mayasari, K., \& Ramdhan, T. (2013). Strategi Pengembangan Agrowisata Perkotaan. Buletin Pertanian Perkotaan. 3 (1). 21-28

Muljadi, A.J dan Warman, H.A. (2014).Kepariwisataan dan Perjalanan. Jakarta: PT.Raja Grafindo Persada.

Suyastiri, N.M. (2012). Pemberdayaan Subak melalui "Green Tourism" Mendukung Keberlanjutan Pembangunan Pertanian di Bali. Vol.8 No.2 Februari 2012. 168-173

Utama, I.G.B.R. (2015). Agrowisata sebagai Pariwisata Alternatif. Researchgate.

Windia, W., Wirartha, M., Suamba, K., \& Sarjana, M. (2007). Model Pengembangan Agrowisata di Bali. Jurnal Soca, 7 (1), 1-14 